\title{
Understanding Perception and Motivation in Sharing Information by Digital Natives in Social Media
}

\section{Memahami Persepsi dan Motivasi dalam Berbagi Informasi oleh Digital Natives di Media Sosial}

\section{Muhammad Rifky Nurpratama}

Paper Type:

Alumni Students from the graduate school, Information management Research Paper and library, Universitas Gadjah Mada

\begin{abstract}
Background of the study: The phenomenon of sharing information by all members of the public, especially digital natives. The phenomenon of sharing information is most visible done on social media such as WhatsApp, Instagram and line. Information sharing activities seem easy to do, especially on social media with a variety of features that have been provided and a variety of information that is spread. Even sharing information can have an impact, both positive like increasing knowledge or negative impacts such as creating information hoaxes.

Purpose: Not yet known explicitly actually what lies behind someone, especially the digital generation natives share information on social media. To find out what is the background of someone sharing information on social media, therefore this study wants to find out from the aspect of perception and motivation regarding information sharing activities carried out by digital natives on social media.

Method: This research uses quantitative methods, while the test carried out is path analysis. The population and sample of this study were S2 students in Information Management and Library and S1 Faculty of Social and Politics UGM. The population was chosen because they want to know the differences in perceptions and motivations of digital generations from the perspective of the level of education and age, apart from the social aspects of each student in sharing information on social media.
\end{abstract}

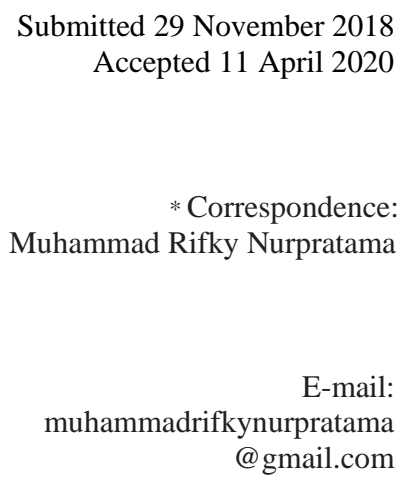

To cite this document:

Nurpratama, M. R. (2020). Understanding Perception and Motivation in Sharing Information by Digital Natives in Social Media, Record and Library Journal, 6(1), 57-68.

Open access under Creative Commons Attribution-Share A like 4.0 International Licence 
Findings: The results of this study found that the perception of MIP students' information sharing was higher than that of FISIPOL students, but on the contrary, the motivation to share information on FISIPOL students was higher than MIP students. The difference is based on the age difference of MIP students who are more mature than FISIPOL students so that their perceptions about sharing information are wiser, but the motivation of FISIPOL students is higher because sharing information is not only for formal matters but also for informal matters such as finding one's reputation and pursuing prizes.

Conclusion: Digital natives' perception in sharing information on social media is sharing information because it is seen to be beneficial to other individuals, sharing information is fun and can invite others to jointly understand and discuss together the latest information. For digital natives motivation in sharing information on social media, intrinsically to meet selfsatisfaction. Examples such as being able to add insight and can discuss with other individuals. Whereas extrinsically is the motivation to share information because it can help others, especially when the information they have is useful and worth sharing. In terms of information sharing activities themselves, the digital natives really understand and pay attention to the type of information and the quality of information that will be shared before they share it with a wide audience.

Keywords: Information Sharing, Digital natives, Social Media, Motivation, Perception

\begin{abstract}
Abstrak
Latar Belakang Masalah: Fenomena berbagi informasi oleh semua kalangan masyarakat, khususnya digital natives, paling terlihat dilakukan di media sosial seperti WhatsApp, Instagram dan Line. Aktivitas berbagi informasi tampak mudah dilakukan khususnya di media sosial dengan berbagai fitur yang sudah disediakan dan berbagai informasi yang tersebar. Bahkan berbagi informasi dapat memberikan dampak, baik positif seperti menambah pengetahuan ataupun dampak negatif seperti menciptakan informasi hoax.
\end{abstract}

Tujuan: Belum diketahui secara eksplisit sebenarnya apa yang melatar belakangi seseorang khususnya generasi digital natives berbagi informasi di media sosial. Untuk mengetahui apa yang melatarbelakangi seseorang berbagi informasi di media sosial, maka dari itu penelitian ini ingin mengetahuinya dari aspek persepsi dan motivasi mengenai aktivitas berbagi informasi yang dilakukan digital natives di media sosial.

Metode: Penelitian ini menggunakan metode kuantitatif, sedangkan uji yang dilakukan adalah analisis jalur. Populasi dan sampel penelitian ini adalah mahasiswa S2 Manajemen Informasi dan Perpustakaan (MIP) dan S1 Fakultas Sosial dan Politik (Fisipol) UGM. Populasi tersebut dipilih karena ingin mengetahui perbedaan persepsi dan motivasi generasi digital natives dari sudut pandang tingkat pendidikan dan umur, selain dari segi sosial masing-masing mahasiswa dalam berbagi informasi di media sosial.

Hasil: Hasil dari penelitian ini ditemukan bahwa perpsepsi mengenai berbagi informasi mahasiswa MIP lebih tinggi daripada mahasiswa Fisipol, namun sebaliknya motivasi berbagi informasi mahasiswa Fisipol lebih tinggi 
daripada mahasiswa MIP. Perbedaan itu, didasari atas perbedaan usia mahasiswa MIP yang lebih matang daripada mahasiswa Fisipol, sehingga persepsi mengenai berbagi informasi lebih bijak, namun motivasi mahasiswa Fisipol lebih tinggi, karena berbagi informasi bukan hanya sekedar untuk hal formal, melainkan juga untuk hal informal seperti mencari reputasi diri dan mengejar hadiah.

Kesimpulan: Persepsi digital natives dalam berbagi informasi di media sosial yaitu berbagi informasi yang dipandang akan bermanfaat bagi individu lain, berbagi informasi itu menyenangkan, dan dapat mengajak orang lain untuk memahami dan berdiskusi bersama tentang informasi terbaru. Untuk motivasi digital natives dalam berbagi informasi di media sosial, secara intrinsik untuk memenuhi kepuasan diri. Contohnya seperti dapat menambah wawasan dan dapat berdiskusi dengan individu lainnya. Sedangkan secara ekstrinsik adalah motivasi berbagi informasi karena dapat membantu orang lain, apalagi ketika informasi yang dimilikinya bermanfaat dan layak untuk dibagikan. Untuk segi kegiatan berbagi informasi itu sendiri, para digital natives sangat memahami dan memperhatikan jenis informasi dan kualitas informasi yang akan dibagikannya sebelum mereka membagikannya kepada khalayak luas.

Kata Kunci: Berbagi Informasi, Digital natives, Media Sosial, Motivasi, Persepsi 


\section{Pendahuluan}

Fenomena kebutuhan informasi saat ini sangat meningkat, karena perkembangan teknologi informasi yang begitu cepat dan masif. Semua aktivitas manusia, baik individu maupun kelompok begitu tergantung dengan teknologi informasi. Fenomena tersebut sangat masif ketika internet masuk dengan membawa segala kemudahan aksesnya serta memuat segala informasi mengenai aktivitas, pekerjaan, tugas, dan sebagainya. Data statistik terakhir mengenai dunia digital yang dirilis Hootsuite (2018) tercatat bahwa pengguna internet di Indonesia sebesar 132,7 juta jiwa dan pengguna media sosial di Indonesia sebesar 130 juta jiwa serta ada peningkatan pengguna aktif media sosial di Indonesia sebesar $23 \%$ atau 24 juta jiwa. Rata-rata orang Indonesia menggunakan internet juga sangat tinggi yaitu 8 jam 51 menit, dan rata-rata menggunakan media sosial yaitu 3 jam 23 menit.

Asosiasi Penyelenggara Jasa Internet Indonesia (APJII) dalam tahun 2017 tercatat bahwa 54,68\% jiwa dari 262 juta penduduk Indonesia yang menggunakan internet. Selain itu, tercatat juga 65,98\% masyarakat di Indonesia menggunakan internet setiap harinya. Aktivitas yang sering dilakukan yaitu mengakses media sosial dengan smartphone sebesar 37\%. APJII (2017) juga merilis data aktivitas pemanfaatan internet dan media sosial yang tecatat paling besar adalah 87,13\% bersosial media, 55,30\% membaca artikel, dan 50,26\% membaca berita sosial / lingkungan. Keuntungan dari pemanfaatan di atas adalah tipe serta konten informasi yang didapat dan dibagikan begitu beragam yang disesuaikan dengan minat tiap individu.

Internet dan media sosial di abad 21 saat ini digunakan oleh setiap golongan usia, namun dengan karakteristiknya yang serba mudah dan cepat serta aplikatif, media sosial menurut APJII (2017) banyak digunakan di ranah usia 19-34 tahun, mereka juga melaporkan bahwa usia dengan penetrasi penggunaan internet tertinggi di Indonesia adalah 75,50\% pada usia 13-18 tahun. Data tersebut semakin menunjukkan bahwa media sosial sangat familiar, popular, dan didominasi penggunaannya oleh para digital natives.

Berdasarkan data tersebut, terlihat bahwa media sosial beranjak menjadi media baru yang populer untuk digunakan masyarakat bahkan menggeser dan menggantikan media lama seperti televisi dan radio. Kebebasan jejaring, keterbukaan informasi menjadi primadona untuk menarik setiap orang dalam mengakses dan menggunakannya, selain untuk kebutuhan komunikasi dengan kawan dan keluarga. Menurut Ahn, Han, Kwak, Moon, \& Jeong (2007) komunikasi jaringan dan berbagi informasi merupakan alasan utama penggunaan media sosial.

Selain itu, menurut Qu, Huang, Zhang, \& Zhang (2011) penggunaan media sosial dalam konteks berbagi informasi menciptakan peningkatan kesadaran situasional maupun keadaan darurat. Dengan kata lain penggunaan media sosial memberikan awareness lebih kepada tiap individu terhadap kondisi lingkungannya. Namun, aktivitas pemanfaatan di atas, tidak bisa terlepas dari dampak bagaimana pemanfaatan tersebut berlangsung. Menurut Cision \& Bates (2009) melaporkan sebanyak 85\% jurnalis mengindikasikan bahwa informasi di media sosial kurang kredibel, daripada media tradisional karena kurangnya verifikasi dan pengecekan fakta. Hal itu, juga dikarenakan sifat media sosial yang bebas dan terbuka, sehingga sumber informasi dari manapun dan siapapun dapat membagi bahkan menciptakan informasi baru atas dasar opini bukan fakta dan kebenaran. Buruknya lagi, karena tipe informasi begitu banyak, sehingga tidak ada penyaringan, sehingga individu cenderung menerima informasi dari siapapun, kapanpun, dan dimanapun lalu dibagikan ulang ke jejaring pertemanan yang lainnya.

Fenomena mengakses informasi mencapai titik fenomenanya yaitu pada aktivitas berbagi informasi yang dilakukan individu maupun kelompok untuk menyampaikan informasi yang diakses, didapat, dan dibacanya kepada orang lain di lingkungan virtual mereka. Aktivitas tersebut sangat mudah dilakukan karena karakteristik internet dan media sosial yang mendukung berbagi dan kecepatannya serta alasan utama penggunaan sosial media adalah untuk berkomunikasi, berjejaring, dan berbagi. Aktivitas berbagi sangat baik dilakukan ketika informasi yang dibagikan memiliki kualitas atau kredibilitas yang baik, contohnya informasi yang berasal dari sumber ternama dan kredibel sehingga dapat membantu mengedukasi individu lain, tetapi ketika informasi memiliki kualitas buruk maka yang ada justru menyebarkan informasi yang menyesatkan atau sering disebut hoax. 
Disebutkan dalam penelitian eksperimen Jiang, Hou, Wang (2016) individu yang sering melakukan re-tweet atau berbagi informasi sering menunjukkan pemahaman yang buruk mengenai isi informasi yang dibagikan dan mereka sering ingat isi informasi yang buruk. Maka dari itu, belum diketahui secara pasti apa yang mendasari individu khususnya digital natives dalam melakukan berbagi informasi, padahal fenomena menunjukkan bahwa banyak kecenderungan tersebarnya hoax dan pemahaman yang buruk terhadap isi informasi yang dibagikan. Berdasarkan fenomena yang dijabarkan tersebut, hadir letak persoalan dari penelitian ini, apa yang mendorong digital natives dalam melakukan berbagi informasi di media sosial?

\section{Metode Penelitian}

Penelitian ini merupakan penelitian kuantitatif analitis, di mana tujuannya untuk menguji hipotesis serta membahas temuan secara analitis. Metode yang digunakan dalam pengumpulan data penelitian ini adalah survei, yang dilakukan dengan bantuan kuesioner sebagai alat pengumpul data. Variabel dalam penelitian ini ada 3 (tiga) yaitu persepsi (X1), motivasi (X2), perilaku berbagi informasi (X3). Variabelvariabel tersebut akan dilakukan uji analisis jalur (path analysis) untuk mengetahui hubungan antar variabel. Populasi dan sampel dalam penelitian ini adalah 25 mahasiswa S2 Manajemen Informasi dan Perpustakaan (MIP) dan 96 mahasiswa S1 Fakultas Sosial dan Politik (Fisipol) UGM. Jumlah sampel tersebut didapat dari rumus yamane, di mana jumlah seluruh mahasiswa Fakultas Sosial dan Politik UGM berjumlah 2283 dan dihasilkan sampel 96 mahasiswa. Sedangkan jumlah keseluruhan mahasiswa S2 Manajemen Informasi dan Perpustakaan UGM adalah 34 dan didapatkan sampel sejumlah 25 mahasiswa. Teknik pengambilan sampel yang digunakan adalah simple random sampling.

\section{Hasil dan Diskusi}

Hasil Uji Analisis Jalur (Path Analysis)

Tabel 1. Matriks pengaruh langsung antar variabel

\begin{tabular}{cccc}
\hline \multicolumn{4}{c}{ Responden Mahasiswa MIP } \\
\hline Variabel & Persepsi & Motivasi & Information sharing \\
Persepsi & 1.000 & 0.679 & 0.747 \\
Motivasi & 0.679 & 1.000 & 0.477 \\
Information & 0.747 & 0.477 & 1.000 \\
sharing & & & \\
& Responden Mahasiswa Fisipol & \\
Variabel & Persepsi & Motivasi & Information sharing \\
Persepsi & 1.000 & 0.755 & 0.564 \\
Motivasi & 0.755 & 1.000 & 0.546 \\
Information & 0.564 & 0.546 & 1.000 \\
sharing & & & \\
Signifikansi korelasi pada level 0,1 (2-tailed) & & \\
\hline
\end{tabular}

Sumber: Hasil Penelitian Oktober 2018

Dalam menghitung pengaruh langsung digunakan rumus sebagai berikut:

1. Berdasarkan jawaban responden MIP, pengaruh persepsi terhadap motivasi $=0,679$ atau $67,9 \%$, dengan tingkat signifikansi 0.000 atau lebih kecil dari $0,1 \rightarrow$ disimpulkan bahwa terdapat pengaruh signifikan persepsi terhadap motivasi.

2. Berdasarkan jawaban responden Fisipol UGM, pengaruh persepsi terhadap motivasi $=0,755$ atau $75,5 \%$, dengan tingkat signifikansi 0.000 atau lebih kecil dari $0,1 \rightarrow$ disimpulkan bahwa terdapat pengaruh signifikan persepsi terhadap motivasi.

3. Berdasarkan jawaban responden MIP, pengaruh persepsi terhadap information sharing $=0,747$ atau $74,7 \%$, dengan tingkat signifikansi 0.000 atau lebih kecil dari 0,1 sehingga pengaruhnya adalah signifikan $\rightarrow$ disimpulkan bahwa terdapat pengaruh signifikan persepsi terhadap information sharing. 
4. Berdasarkan jawaban responden Fisipol UGM, pengaruh persepsi terhadap information sharing = 0,564 atau 56,4\%, dengan tingkat signifikansi 0.000 atau lebih kecil dari 0,1 sehingga pengaruhnya adalah signifikan $\rightarrow$ disimpulkan bahwa terdapat pengaruh signifikan persepsi terhadap information sharing

5. Berdasarkan jawaban responden MIP, pengaruh motivasi terhadap information sharing $=0,477$ atau 47,7\%, dengan tingkat signifikansi 0.014 atau lebih kecil dari 0,1 sehingga pengaruhnya adalah signifikan $\rightarrow$ disimpulkan bahwa terdapat pengaruh signifikan motivasi terhadap information sharing.

6. Berdasarkan jawaban responden Fisipol UGM, pengaruh motivasi terhadap information sharing $=$ 0,546 atau 54,6\%, dengan tingkat signifikansi 0.000 atau lebih kecil dari 0,1 sehingga pengaruhnya adalah signifikan $\rightarrow$ disimpulkan bahwa terdapat pengaruh signifikan motivasi terhadap information sharing

Sedangkan untuk perhitungan pengaruh tidak langsungnya adalah sebagai berikut:

Tabel 2. Pengaruh Variabel Persepsi dengan Variabel Information sharing melalui Variabel Motivasi

Pengaruh Variabel Persepsi dengan Variabel Information sharing melalui Variabel Motivasi

\begin{tabular}{cccc}
\hline & Variabel & $\begin{array}{c}\text { Standardized } \\
\text { Coefficients }\end{array}$ & Sig. \\
Persepsi --> Motivasi --> & Persepsi --> Information sharing & 0.786 & .000 \\
Information sharing (MIP) & Motivasi --> Information sharing & -0.057 & .766 \\
Persepsi --> Motivasi --> & Persepsi --> Information sharing & 0.353 & .000 \\
Information sharing (Fisipol) & Motivasi --> Information sharing & 0.279 & .031 \\
\hline
\end{tabular}

Sumber: Hasil Penelitian Oktober 2018

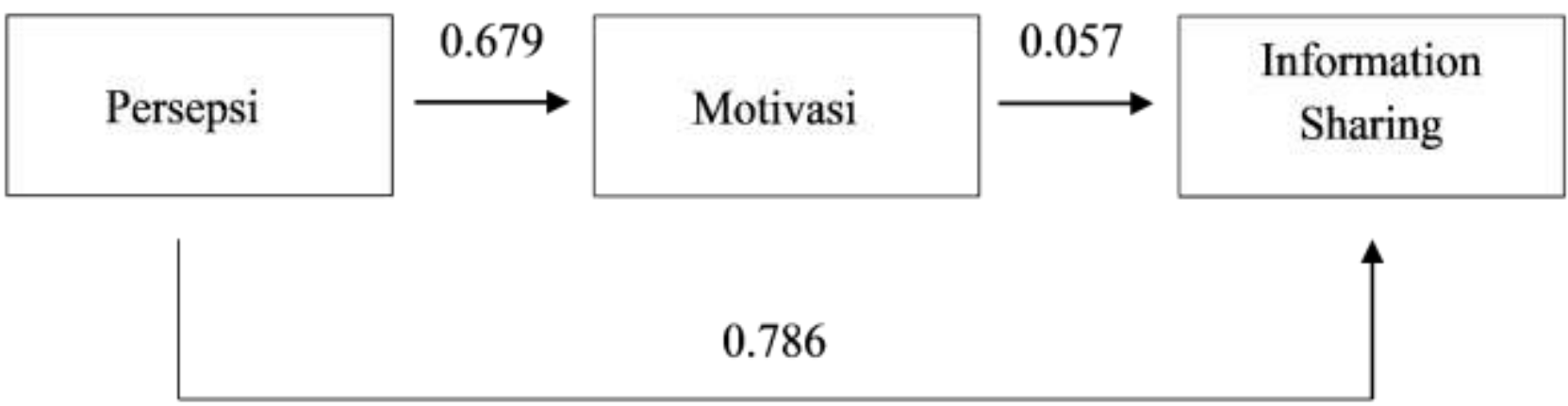

Gambar 1. Diagram hubungan dari persepsi, motivasi dan information sharing (MIP)

Diketahui pengaruh langsung yang diberikan persepsi terhadap information sharing sebesar 0.786. Sedangkan pengaruh tidak langsung persepsi melalui motivasi terhadap information sharing adalah perkalian antara nilai persepsi terhadap motivasi dengan nilai motivasi terhadap information sharing yaitu $0,679 \times 0.057=0.038703$. Berdasarkan hasil perhitungan di atas diketahui bahwa nilai pengaruh langsung sebesar 0,786 dan pengaruh tidak langsung sebesar 0.038703 yang berarti bahwa nilai pengaruh langsung lebih besar daripada nilai pengaruh tidak langsung, sehingga menunjukkan bahwa secara langsung persepsi berpengaruh signifikan terhadap information sharing tanpa melalui motivasi. 


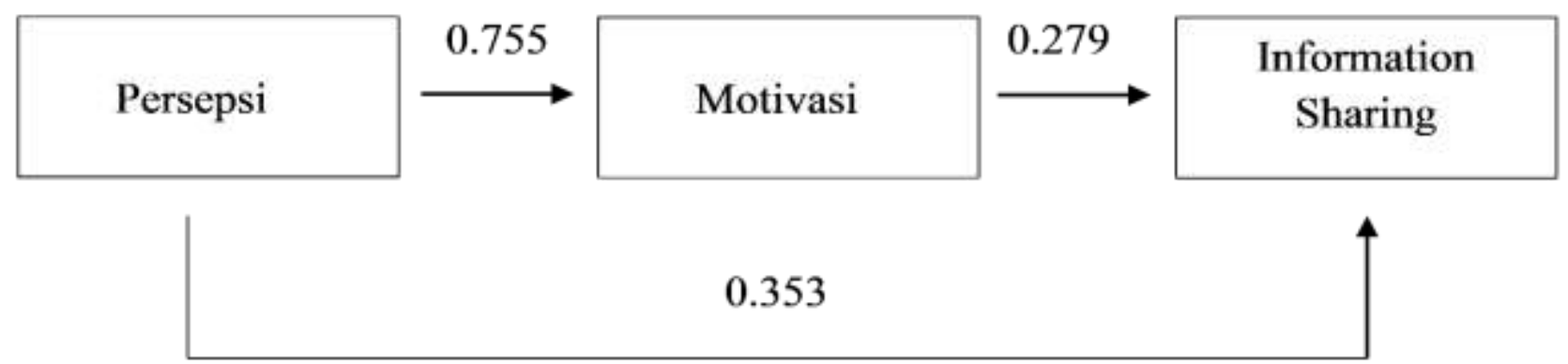

Gambar 2. Diagram hubungan dari persepsi, motivasi dan information sharing (Fisipol)

Diketahui pengaruh langsung yang diberikan persepsi terhadap information sharing sebesar 0.353. Sedangkan pengaruh tidak langsung persepsi melalui motivasi terhadap information sharing adalah perkalian antara nilai persepsi terhadap motivasi dengan nilai motivasi terhadap information sharing yaitu $0.755 \times 0.279=0.210645$. Berdasarkan hasil perhitungan di atas diketahui bahwa nilai pengaruh langsung sebesar 0.353 dan pengaruh tidak langsung sebesar 0.210645 yang berarti bahwa nilai pengaruh langsung lebih besar daripada nilai pengaruh tidak langsung, sehingga menunjukkan bahwa secara langsung persepsi berpengaruh signifikan terhadap information sharing tanpa melalui motivasi.

\section{Digital natives dan aktivitas berbagi informasi di media sosial}

Temuan dari penelitian ini bahwa berbagi informasi di media sosial oleh digital natives, pertama dilakukan atas dasar kebutuhan informasi yang harus mereka penuhi seperti mengerjakan tugas atau pekerjaan karena untuk mendapatkan berbagai referensi dan perspektif individu lain. Kebutuhan selanjutnya adalah untuk bersosialisasi di mana berbagi informasi berguna untuk mendekatkan diri dengan individu lain dan menyamakan bahan pembicaraan sehingga dapat menambah wawasan juga. Sejalan dengan konsep yang diungkapkan Fang \& Chiu (2010) bahwa berbagi informasi didefinisikan sebagai budaya interaksi sosial yang melibatkan pertukaran pengetahuan, pengalaman, dan keterampilan. Begitu juga jika berbagi informasi dipandang dalam lingkup konsep user and gratification, menurut studi Lee dan Ma (2012) menemukan bahwa niat berbagi informasi orang didorong oleh motif gratifikasi penting seperti mencari informasi, mencari status, dan bersosialisasi.

Keinginan mereka berbagi informasi untuk mendapatkan bahan pembicaraan, menyamakan frekuensi pembicaraan, mendapatkan perspektif lain dalam mengerjakan tugas tidak lepas dari konsep timbal balik. Menurut Gouldner (1990) pendorong penting dari berbagi informasi adalah timbal balik, karena dianggapnya timbal balik dapat menjadi norma sosial bahwa orang harus membantu orang lain yang sudah membantunya dan tidak boleh merugikannya. Begitu halnya menurut Clarke dalam Fulton (2009) menyatakan bahwa information sharing dapat terjadi di antara individu-individu yang memang sedang membutuhkan pertukaran informasi. Dilengkapi pernyataaan Sonnenwald dalam Du (2012) bahwa information sharing bertujuan untuk mengubah citra seseorang tentang dunia dan mengembangkan pemahaman bersama, seperti yang terlihat dalam penelitian ini yaitu berbagi informasi untuk bersosialisasi.

Di dalam penelitian ini, digital natives juga setuju bahwa informasi yang didapat akan dibagikan kembali, dengan syarat jika informasi itu penting dan untuk cek validitasnya. Sejalan dengan konsep Rioux (2004) bahwa berbagi informasi merupakan perilaku informasi yang menyenangkan, di mana individu menyimpan dan mengingat kebutuhan informasi individu lain, dikaitkan dengan informasi yang didapatnya, lalu dibagikan ke individu lain.

Ketika berbagi informasi digital natives di media sosial, subjek tujuan pun mereka pilah-pilah baik kepada perorangan atau kelompok. Perorangan lebih dipilih oleh mahasiswa MIP karena lebih mudah dan intens sedangkan subjek kelompok lebih dipilih oleh mahasiswa Fisipol karena lebih efektif dalam menyebarkan informasi ke khalayak luas. Secara konsep, pemilihan subjek dalam berbagi 
informasi diungkapkan oleh Huaye Li, Yasuaki Sakamoto (2014) jika seseorang mengasumsikan sekelompok pengguna berkontribusi dalam membangun opini bersama di media sosial, maka kelompok tersebut akan dianggap penting bagi individu terkait ketika mencari informasi dengan ketertarikan yang sama.

Berbagi informasi di media sosial oleh digital natives juga memperhatikan kualitas informasi yang akan dibagikan. Mereka cenderung membagikan informasi atas dasar kecocokan dengan apa yang dibutuhkannya seperti aktivitas keseharian dan mood. Karena menurut Pilerot (2012) dalam information sharing, secara eksplisit yang dibagikan adalah informasi. Informasi sendiri merupakan sesuatu yang membantu dalam memahami dan menghadapi situasi yang sedang dialami. Frekuensi digital natives dalam membagikan informasi diketahui adalah 1-2 kali dalam sehari. Data yang didapat tersebut sejalan dengan pernyataan mereka bahwa lebih memilih untuk mengonsumsi informasi secara pribadi daripada membagikan informasi ke media sosial. Alasannya, adalah karena mereka mementingkan kualitas informasi, jika informasi yang ditemukan tidak berkualitas atau tidak bermanfaat maka tidak akan dibagikan, sebaliknya jika dianggap berkualitas dan bermanfaat maka akan dibagikan. Maka dari itulah frekuensi berbagi informasi mereka terbatas pada 1-2 kali dalam sehari.

Jenis informasi yang paling sering dibagikan adalah personal dan kasual. Jika mahasiswa MIP lebih kepada informasi personal dengan alasan agar informasi tersebut dapat terekam karena mengandung momen yang tidak dapat diulang. Sedangkan mahasiswa Fisipol memilih dua informasi yang sama-sama sering dibagikan yaitu personal dan kasual dengan alasan untuk berbagi kepada individu terdekat dan keluarga, serta sifat informasi ringan dengan artian menyangkut informasi yang dekat secara personal seperti hobi, aktivitas kegemaran, dan tidak mengandung sisi kontroversial.

\section{Persepsi digital natives dalam berbagi informasi di media sosial}

Persepsi digital natives yang notabene adalah mahasiswa S2 MIP dan S1 Fisipol UGM dalam berbagi informasi di media sosial dalam penelitian ini diukur dari beberapa indikator, yaitu interpretasi prasyarat dan interpretasi dampak berbagi informasi di media sosial. Tanggapan mahasiswa MIP dan Fisipol cenderung dominan positif yaitu berpersepsi bahwa membagikan informasi tidak menganggu aktivitas keseharian. Alasan utamanya adalah waktu dan kemudahan akses, dalam berbagi informasi dapat mengatur waktu yang tepat untuk melakukannya, dan lagipula akses untuk berbagi informasi sangat mudah. Jika persepsi negatif sama-sama beralasan bahwa masih ada aktivitas lain yang dapat dilakukan selain berbagi informasi, dan berpotensi menganggu fokus.

Secara keseluruhan analisis teoritik dari semua indikator melalui tanggapan-tanggapan mereka mengenai persepsi terhadap information sharing misalnya dimulai dari ketika individu belum paham mengenai informasi yang akan dibagikan, maka tidak akan dibagikan. Hal itu dilakukan untuk meminimalisir jika individu tidak bisa menjawab ketika ada pertanyaan dari rekan dan juga agar tidak mengalami rasa atau pengalaman malu jika informasi yang dibagikan ternyata tidak kredibel sehingga individu dapat mempertanggungjawabkan aktivitas berbagi informasinya.

Tanggapan-tanggapan mereka semua mengenai persepsi, sesuai dan dapat dijelaskan secara konsep. Di mana bahwa keputusan berbagi mereka dipengaruhi oleh persepsi batas-batas yang dibentuk oleh rekan-rekan dan pengetahuan yang dihasilkan secara kolektif. Dengan kata lain, rekan dan pengetahuan yang diterima dari lingkungan sekitarnya dapat mempengaruhi persepsi individu terhadap berbagi informasi yang dilakukan (Shari S.C. Shang, Ya-Ling Wu, Eldon Y. Li, 2017).

Konsep lain menurut Thoha (2015) yaitu faktor-faktor yang mempengaruhi persepsi terdiri dari faktor internal yaitu meliputi perasaan, sikap dan kepribadian individu, prasangka, keinginan atau harapan, perhatian (fokus), proses belajar, keadaan fisik, gangguan kejiwaan, nilai dan kebutuhan juga minat. Sedangkan faktor eksternal meliputi latar belakang pribadi, informasi yang diperoleh, pengetahuan dan kebutuhan sekitar, intensitas, ukuran, keberlawanan, pengulangan gerak, hal-hal baru dan familiar atau ketidak asingan suatu objek. Begitu juga menurut Walgito (2007) persepsi juga dipengaruhi oleh pengalaman, proses belajar, dan pengetahuannya. 


\section{Motivasi digital natives dalam berbagi informasi di media sosial}

Motivasi digital natives mahasiswa S2 MIP dan S1 Fisipol UGM dalam berbagi informasi di media sosial dalam penelitian ini diukur dari beberapa indikator, yaitu motivasi intrinsik dan ekstrinsik dalam berbagi informasi di media sosial. Analisis teoritik dari motivasi intrinsik, ditinjau dari teori evaluasi kognitif yang diungkapkan E.L. Deci, W.F. Cascio, J. Krusell (1975), perilaku berbagi didorong oleh motivasi ekstrinsik dan intrinsik. Motivasi intrinsik terjadi ketika suatu kegiatan dilakukan untuk kepuasan permintaan langsung dan perilaku didorong oleh beberapa perasaan psikologis endogen kompetensi pribadi dan penentuan nasib sendiri dalam menangani situasi (E.L. Deci, W.F. Cascio, J. Krusell, 1975).

Pengguna dalam masyarakat virtual sangat otonom dan proses kognitif mereka berbagi informasi dapat dipengaruhi oleh kondisi seperti dinamika orang yang berinteraksi dan kualitas konten yang mereka bagikan. Terbukti dari tanggapan mereka mengenai motivasi intrinsik untuk berbagi informasi karena percaya terhadap individu / kelompok yang ingin dituju. Mereka menyatakan bahwa tidak nyaman jika individu yang dituju tidak kenal bahkan tidak dipercaya. Begitu juga mereka menganggap individu maupun lingkungan yang ingin dibagikan informasi adalah individu yang pintar dan terpercaya sehingga berbagi informasi dilakukan dengan nyaman dan terkendali. Berdasarkan apa yang telah mereka lakukan, semakin menunjukkan bahwa sesuai pernyataan (Shari S.C. Shang, Ya-Ling Wu, Eldon Y. Li, 2017) kebanyakan orang tidak berbagi sumber daya pribadi lainnya dengan orang-orang yang tidak pernah mereka temui, kecuali mereka tahu bahwa latar belakang orang ini adalah benar dan nyata. Ryan \& Deci (2000) juga mendefinisikan motivasi intrinsik sebagai melakukan suatu kegiatan untuk kepuasan yang melekat pada diri individu tersebut. Kepuasaan diri yang terlihat dari tanggapan responden yaitu seperti dapat mengambil manfaat dari informasi yang dibagikan, menambah bahan diskusi, menilai karakteristik diri dan individu lain, serta dapat sebagai aktivitas mengekspresikan diri di lingkungan media sosial. Keuntungan pribadi di dalam motivasi intrinsik individu, sejalan seperti yang disebutkan oleh Munar \& Jacobsen (2014) yaitu meliputi ikatan sosial, harga diri, menikmati aktivitas online, kepercayaan, dan timbal balik.

Begitu juga motivasi ekstrinsik dapat ditinjau dari teori evaluasi kognitif E.L. Deci, W.F. Cascio, J. Krusell (1975), perilaku berbagi didorong oleh motivasi ekstrinsik dan intrinsik. Motivasi ekstrinsik berarti bahwa individu termotivasi ketika kepuasan tidak dihasilkan dari isi kegiatan itu sendiri tetapi dari penghargaan eksternal yang diberikan oleh komunitas, dan dengan demikian perilaku individu dapat ditimbulkan oleh nilai-nilai yang dirasakan berasal dari interaksi (H. Lin, 2007). Konsep tersebut dapat dibuktikan dalam penelitian ini, yaitu dengan hasil bahwa motivasi ekstrinsik digital native dalam berbagi sosial karena ingin bermanfaat bagi orang lain sebagai salah satu tujuan hidup, peduli dengan lingkungan di sekitarnya. Kesesuaian tersebut tergambar jelas dari beberapa tanggapan responden yang dapat disimpulkan bahwa dalam berbagi informasi, mereka selalu berupaya informasi yang dibagikan dapat memberikan manfaat. Mereka juga memilih bermanfaat bagi individu lain daripada berbagi informasi untuk meningkatkan reputasi diri semata. Tanggapan tersebut juga sesuai dengan pernyataan J.C. Mowen, H. Sujan (2005) bahwa individu yang bermotivasi secara altruisis berpikir bahwa secara sukarela membantu orang lain adalah hal yang benar untuk dilakukan.

Begitu halnya, sejalan dengan pernyataan Fu et al. (2017) juga mengatakan selain motivasi intrinsik juga ada motivasi ekstrinsik individu dalam berbagi konten di Facebook yaitu communal motives yang meliputi membuat koneksi, perhatian terhadap orang lain, dan kegembiraan di dalam kelompoknya. Namun ada motivasi ekstrinsik yang tidak dimiliki digital natives dalam berbagi informasi yaitu tidak untuk mengejar hadiah ataupun tidak karena tuntutan dari pihak lain. Menurut mereka, hadiah dan tuntutan pihak lain tidak selalu hadir dan dirasakan karena justru menganggu diri secara personal seperti keterpaksaan, akhirnya pun justru akan berdampak pada individu lain misalnya seperti spaming informasi di media sosial.

\section{Kesimpulan}

Penelitian ini menghasilkan banyak temuan mengenai aktivitas berbagi informasi oleh digital 
natives di media sosial, mulai dari persepsi mengenai berbagi informasi, motivasi berbagi informasi, dan berbagi informasi itu sendiri. Ditemukan hasil tanggapan responden mengenai pernyataan persepsi berbagi informasi di media sosial dari kuesioner bahwa persepsi mahasiswa MIP dan Fisipol sama-sama baik, dengan arti mereka berpandangan bahwa berbagi informasi memang bermanfaat dan menyenangkan untuk dilakukan dan tidak menghabiskan waktu atau menganggu aktivitas keseharian. Hal tersebut, dikarenakan mereka berbagi informasi untuk mengajak orang bersama-sama mengetahui informasi baru dan terkini, sehingga dapat menambah wawasan dan dapat terjadi diskusi atau timbal balik yang positif, baik itu saran maupun kritik. Mereka juga berpersepsi bahwa ketika ingin membagikan informasi maka perlunya langkah-langkah pemahaman, penilaian kelayakan, dan sumber informasi terkait, agar tidak terjadi berbagi informasi hoax, palsu, atau menyesatkan sehingga ditakutkan terjadi chaos. Dengan kata lain, langkah-langkah tersebut berguna untuk menyaring kualitas informasi sebelum dibagikan. Namun, ada temuan yang menunjukkan adanya perbedaan mengenai persepsi terhadap berbagi informasi dari mahasiswa MIP dan Fisipol, perbedaan itu hadir pada temuan bahwa mahasiswa Fisipol berpandangan jika informasi yang dibagikan tidak bersifat penting atau mengandung pengetahuan, seperti misalnya informasi hiburan yaitu humor, meme, video lucu maka tidak perlu melalui langkah pemahaman, penilaian kelayakan isi, dan sumber. Hal tersebut, menurut mereka informasi hiburan tidak perlu untuk dinilai, karena sifatnya menghibur, dan jika sumber dan isinya dinilai maka sudah pasti tidak layak. Informasi hiburan seperti meme, video lucu kebanyakan diambil dari akun-akun media sosial receh / tidak valid.

Temuan lainnya mengenai motivasi berbagi informasi, mahasiswa Fisipol justru lebih tinggi daripada mahasiswa MIP. Hal itu dikarenakan mahasiswa Fisipol banyak yang menanggapi bahwa berbagi informasi dilakukan salah satunya untuk mengejar hadiah give away dan untuk meningkatkan reputasi pribadi. Mahasiswa Fisipol beranggapan bahwa membagikan informasi tidak hanya untuk aktivitas formal dan serius, melainkan juga untuk hal-hal ringan dan menghibur, sekaligus berguna untuk branding diri di media sosial, misalnya agar dianggap melek informasi. Namun, bagi mahasiswa MIP beranggapan bahwa membagikan informasi harus bermanfaat bagi diri sendiri dan orang lain.

Perbedaan itu sangat dimungkinkan karena faktor usia dan pendidikan, rata-rata perbedaan usia diantara mahasiswa S2 dan S1 berbeda sekitar lima tahun, sehingga kematangan usia membuat mahasiswa S2 lebih bijak dalam membagikan informasi dengan alasan untuk kebermanfaatan bersama bukan hanya sekedar keuntungan pribadi, dan pada usia mahasiswa S1 yang masih sangat rentan dan aktif untuk mencari jati diri.

Faktor pendidikan juga memengaruhi, di mana pada S2 khususnya MIP, pembelajaran mengenai berbagi informasi dan media sosial ditekankan pada nilai-nilai esensial aktivitas dan perilaku berbagi informasi, sedangkan pembelajaran di S1, khususnya Fisipol cenderung kepada cara berbagi informasi dan penggunaan media sosial yang baik dan benar.

Secara keseluruhan motivasi mahasiswa MIP dan Fisipol yang termasuk di dalam digital natives secara intrinsik adalah untuk kepuasan diri, seperti menambah wawasan diskusi, kepercayaan, dan timbal balik. Motivasi ekstrinsik dalam berbagi informasi untuk kebermanfaatan dan membantu orang lain, karena secara keseluruhan tanggapan digital natives lebih memilih berbagi informasi untuk bermanfaat bagi banyak orang daripada hanya mementingkan kepentingan pribadi.

Selain persepsi dan motivasi yang terungkap, intensitas berbagi informasi juga diketahui yaitu dilakukan satu hingga dua hari sekali. Hal tersebut, tergolong kecil namun bukan berarti negatif, karena intensitas mereka dalam berbagi informasi yang sedikit dikarenakan mereka para digital natives sadar bahwa jika berbagi informasi harus dan perlu melalui proses pemahaman, penilaian kelayakan isi, dan sumber informasi terkait, sehingga kualitas informasi yang dibagikan terjamin. Berkaitan dengan kualitas informasi, jenis informasi yang dibagikan oleh digital natives adalah informasi personal dan kasual. Berbagi informasi personal karena mereka ingin berbagi momen yang tidak dapat diulang, sedangkan berbagi informasi kasual dikarenakan mengandung informasi mengenai kegemaran/hobi serta tidak mengandung informasi yang kontroversial/ringan untuk dibagikan, dan dijadikan bahan diskusi bersama. Berdasarkan semua hasil temuan, maka dapat disimpulkan bahwa digital natives memiliki persepsi dan 
motivasi yang tinggi, serta baik dalam melakukan berbagi informasi di media sosial.

\section{Ucapan Terima Kasih}

Terimakasih kepada dosen pembimbing penulis, Prof. Dr. Partini, S.U. dan para responden mahasiswa MIP dan Fisipol UGM yang telah meluangkan waktunya untuk mengisi dan memberikan tanggapan mengenai topik penelitian ini. Beserta semua pihak yang berjasa, dan tidak dapat disebutkan satu-persatu.

\section{Referensi}

Ahn, Y., Han, S., Kwak, H., Moon, S., \& Jeong, H. (2007). Analysis of topological characteristics of huge online social networking services analysis of topological characteristics of huge online social networking services, (may). https://doi.org/10.1145/1242572.1242685

Asosiasi Penyelenggara Jasa Internet Indonesia. (2017). Penetrasi \& perilaku pengguna internet indonesia

Bimo Walgito. (2002). Pengantar Psikologi Umum. Yogyakarta: Andi Offset

Cision, \& Bates. (2009). Social Media \& online usage study. Washington, DC, 124.

Du, J. T. (2012). Information use and information sharing in marketing: A diary study. ASIST 2012.

E.L. Deci, W.F. Cascio, J. Krusell, Cognitive evaluation theory and some comments on the Calder- Staw critique, J. Pers. Soc. Psychol. 1 (1) (1975) 81- 85

Fang, Y.-H., \& Chiu, C.-M. (2010). In justice we trust: Exploring knowledge-sharing continuance intentions in virtual communities of practice. Computers in Human Behavior, 26, 235-246.

Fu, P., Wu, C., \& Cho, Y. (2017). Computers in Human Behavior What makes users share content on facebook? Compatibility among psychological incentive, social capital focus, and content type. Computers in Human Behavior, 67, 23-32. https://doi.org/10.1016/j.chb.2016.10.010

Fulton, C. (2009). Quid Pro Quo: Information Sharing in Leisure Activities. Library Trends, 57(4), 753 768. https://doi.org/10.1353/lib.0.0056

Gouldner, A. W. (1960). The norm of reciprocity: A preliminary statement. American Sociological Review, 25(2), 161-178.

Hootsuite. (2018). Digital in 2018 in Southeast Asia. We Are Social. Retrieved from https://www.slideshare.net/wearesocial/digital-in-2018-in-southeast-asia-part-2-southeast86866464\%0Ahttps://www.slideshare.net/wearesocial/digital-in-2018-in-southeast-asia-part1-northwest-86866386\%0Ahttps://www.slideshare.net/wearesocial/digital-in-20.

J.C. Mowen, H. Sujan, Volunteer behavior: a hierarchical model approach for investigating its trait and functional motive antecedents, J. Consum. Psychol. 5 (2) (2005) 170-182.

Jiang, T., Hou, Y., \& Wang, Q. (2016). Does micro-blogging make us "shallow"? Sharing information online interferes with information comprehension. Computers in Human Behavior, 59, 210 214. https://doi.org/10.1016/j.chb.2016.02.008

Lee, C. S., \& Ma, L. (2012). News sharing in social media: The effect of gratifications and prior experience. Computers in Human Behavior, 28(2), 331-339. https://doi.org/10. 1016/j.chb.2011.10.002

Li, H., \& Sakamoto, Y. (2014). Computers in Human Behavior Social impacts in social media: An examination of perceived truthfulness and sharing of information. Computers in Human Behavior, 41, 278-287. https://doi.org/10.1016/j.chb.2014.08.009

Lin, H. (2007). Effects of extrinsic and intrinsic motivation on employee knowledge sharing intentions, 33(2), 135-149. https://doi.org/10.1177/0165551506068174

Miftah Thoha. (2004). Perilaku Organisasi, Konsep Dasar dan Aplikasinya. Jakarta: Raja Grafindo Persada

Munar, A. M., \& Jacobsen, J. K. S. (2014). Motivations for sharing tourism experiences through social media, 43, 46-54. https://doi.org/10.1016/j.tourman.2014.01.012

Ola Pilerot, (2012) "LIS research on information sharing activities - people, places, or information", 
Journal of Documentation, Vol. 68 Issue: 4, pp.559-581, https://doi.org/10.1108/00220411211239110.

Qu, Y., Huang, C., Zhang, P., \& Zhang, J. (2011). Microblogging after a major disaster in China : a case study of the 2010 Yushu earthquake microblogging after a major disaster in China: a case study of the 2010 Yushu earthquake, (January). https://doi.org/10.1145/1958824.1958830

Rioux, K. (2004). Information acquiring-and-sharing in internet-based environments : An exploratory study of individual user behaviors. The University of Texas at Austin.

Ryan, R. M., \& Deci, E. L. (2000). Intrinsic and extrinsic motivations : classic definitions and new directions, 67, 54-67. https://doi.org/10.1006/ceps.1999.1020

Shang, S. S. C., Wu, Y., \& Li, E. Y. (2017). Information \& Management Field effects of social media platforms on information-sharing continuance : Do reach and richness matter?, 54, 241-255.

To cite this document:

Nurpratama, M. R. (2020). Understanding Perception and Motivation in Sharing Information by Digital Natives in Social Media,

Record and Library Journal, 6(1), 57-68.

Open access under Creative Commons Attribution-Share A like 4.0 International Licence 